Title: The Relationship between Environmental Management Systems and Organisational Innovations

Authors: Josep Llach ${ }^{\mathrm{a}}$, Rodolfo de Castro ${ }^{\mathrm{a}}$, Andrea Bikfalvia, Frederic Marimon ${ }^{\mathrm{b}}$

${ }^{a}$ Department of Business Administration and Product Design, University of Girona.

${ }^{b}$ Department of Organization, International University of Catalonia.

\begin{abstract}
:
This study provides empirical evidence of the nature of the relationship between environmental management systems and organisational innovations. Utilising a sample of Spanish manufacturing firms, the study reports on the implementation of the ISO 4000 environmental quality standards and the relationship of such implementation with organisational innovations in the firm. The study presents several implications of interest for practitioners, academics, and policy makers.
\end{abstract}

Keywords: Environmental management system; organizational innovation; ISO 14000; Spain

JEL code: L15; L22; L23

${ }^{1}$ Corresponding author: Josep Llach

Address: University of Girona - Campus Montilivi, Building EPS-1, Av. Lluís Santaló s/n, 17071 Girona (Spain)

Tel: $(+34) 972418382$

Fax: $(+34) 972418399$

e-mail: josepllach@udg.edu 


\section{The Relationship between Environmental Management Systems and Organisational Innovations}

\section{Introduction}

In addressing the challenges of an ever-changing economic environment, businesses in all sectors have been forced to innovate by introducing new products and services, designing new processes, and implementing new organisational and management techniques (Lay and Mies, 1999). In general, the literature on innovation has focused mainly on the development and introduction of new products and services, which probably reflects the fact that procedural and organisational innovations are complicated phenomena that are more difficult to characterise and analyse than is the case with innovations of specific goods and services.

Nevertheless, organisational innovations are extremely important. There is evidence that firms maintaining traditional systems of work are gradually being replaced by companies that utilise innovative organisational styles and structures that are designed to unlock the skills, creativity, and commitment of their employees (EC, 2002). Tidd et al. (2005, p. 5) emphasised the importance of organisational innovation when they made the following observation:

... whilst competitive advantage can come from size, or possession of assets, etc. the pattern is increasingly coming to favour those organizations which can mobilize knowledge and technological skills and experience to create novelty in their offerings (product/service) and the ways in which they create and deliver those offerings.

Against this background, the situation in Spain is of interest. In a recent 'Global Competitiveness Report' (World Economic Forum, 2008), Spain received relatively high rankings in terms of competitiveness (29th position in the world), size of market (12th), sophistication of business sector (24th), technological readiness (29th), infrastructure (22nd), education and training (30th), and macroeconomic fundamentals (30th). However, its institutional environment (43rd), innovation potential (39th), and inflexible labour market (96th) received much lower rankings. It is thus apparent that innovation in general, and organisational innovation in particular, have considerable need for improvement in Spain.

Nevertheless, the performance of Spain is not as bleak with regard to organisational innovations in the area of environmental protection and sustainability. According to the World Business Council for Sustainable Development (WBCSD, 2008), businesses and governments across the world are creating new jobs and markets by investing in new forms of energy, retrofitting buildings and equipment, and managing forests and other ecosystems. In this regard, 
environmental management systems (EMSs) are increasingly providing innovative firms with a competitive advantage, and the Spanish Ministry of Industry, Tourism and Commerce (2005) has encouraged business innovation systems in Spain to proceed in parallel with environmentally sustainable development. This appears to be happening. Figures provided by the ISO Survey 2008 ranked Spanish firms third in the worldwide rankings for environmental certification (ISO 14001). However, it should be noted that the same survey noted a deterioration in Spanish 'ecoefficiency', which is a term used to refer to the production of economically valuable goods and services while reducing the ecological impacts of production. Given that improved 'ecoefficiency' translates into an increase in resource productivity and competitive advantage, the link between organisational innovation and environmental sustainability is becoming an increasingly crucial issue for Spanish firms.

The main purpose of the present paper is, therefore, to analyse the relationship between various organisational innovations and the implementation of environmental management systems among Spanish manufacturing firms. The remainder of the paper is structured as follows. In Section 2, the theoretical background to the study is presented, including a discussion of the concept of organisational innovations and a description of environmental management systems; the formulation of the study's hypotheses is also presented in this section. In Section 3, the methodology of the empirical study is described. The results of the empirical study are presented in Section 4. The paper concludes with a summary of the major findings and implications.

\section{Theoretical background and hypotheses}

\subsection{Organisational innovations}

For many decades, the term 'innovation' has been synonymous with technological innovation, and it has only been since the late 1990s that the concept of 'organisational innovation' has gradually gained the attention of researchers and practitioners. However, even after almost two decades, the notion of 'organisational innovation' has not reached the degree of acceptance enjoyed by the well-established concept of technological innovation. The reasons for this can be categorised into three main groups: (i) definition; (ii) measurement; and (iii) characteristics. Each of these is discussed briefly below.

\subsubsection{Definition}

With regard to problems of definition, Lam (2005) has noted that the concept of 'organisational innovation' has been subject to such a variety of interpretations that a unique definition of the term is virtually impossible. Nevertheless, various attempts to delineate the concept have been made. 
Several authors have suggested that the term 'organisational innovation' refers generally to the creation or adoption of an idea or behaviour that is new to a given organisation (Daft, 1978; Damanpour and Evan, 1984; Damanpour, 1996). More specifically, the Oslo Manual (OECD, 2005), which provides guidelines for collecting and interpreting innovation data, has stated that an 'organisational innovation' is the implementation of a new organisational method in a firm's business practices, workplace organisation, or external relations.

Whatever the precise definition, it can be said that the distinguishing features of an organisational innovation, as compared to other organisational changes, are: (i) that it has not been used before in the firm; and (ii) that it is the result of strategic decisions taken by management.

According to Armbruster et al. (2008), such organisational innovations can be divided into: (i) structural organisational innovations; and (ii) procedural organisational innovations. In this regard, Armbruster et al. (2008, p. 646) described structural organisational innovations as those that:

... influence, change and improve responsibilities, accountability, command lines and information flows as well as the number of hierarchical levels, the divisional structure of functions, or the separation between line and support functions. Such structural organizational innovations include, for instance, the change from an organizational structure of functions into product- or customer-oriented lines, segments, divisions or business units.

On the other hand, Armbruster et al. (2008, p. 646) defined procedural organisational innovations as those that:

... affect the routines, processes and operations of a company. Thus, these innovations change or implement new procedures and processes within the company, such as simultaneous engineering or zero buffer rules. They may influence the speed and flexibility of production or the quality of production.

\subsubsection{Measurement}

With regard to measurement, it has been suggested that innovation, by its very nature as a novelty, is inherently impossible to quantify and measure (Smith, 2005). Moreover, because organisational innovations often involve new arrangements for interactions among personnel, objective measurement is difficult; as Benders et al. (2001, p. 205) have observed in commenting on the problem of measuring 'teamwork', there are always 'difficulties in operationalizing an immaterial phenomenon such as group work".

Despite these inherent difficulties, some standard indicators for monitoring innovation have been developed. Such monitoring has achieved greater standardisation with technological 
innovation than is the case with organisational innovation, but large-scale surveys measuring the extent of organisational innovations have been undertaken (Armbruster et al., 2008). Nevertheless, it remains true that discrepancies in terminology and criteria have added an unwanted degree of complexity to the problem of measuring the incidence and extent of organisational innovation. As Osterman (1994, p. 174) has observed: "systematic studies on the determinants of adoption rates are extremely scarce".

\subsubsection{Characteristics}

With regard to the characteristics of organisational innovation, the general (and perhaps rather vague) nature of the label of 'organisational innovation' has meant that it has become something of an umbrella term for a wide variety of strategies and actions. It is thus extremely difficult to specify the precise characteristics of an 'organisational innovation'; indeed, Benders et al. (2001, p. 205) have commented that many characteristics of organisational innovations, such as the key issue of teamwork, have become the subject of "much speculation [but] little data". Nevertheless, without attempting to provide an exhaustive list of the precise characteristics of organisational innovation, three features of the concept are important to the purposes of the present study: (i) complexity; (ii) dynamism; and (iii) gradualism of implementation. These are briefly described below.

With regard to complexity, the inherent intricacy of much technological innovation is well recognised. This is no less applicable to organisational innovations. In particular, the intangible nature of the interpersonal relationships that characterise many organisational innovations adds even greater complexity to the implementation and assessment of these phenomena.

With regard to dynamism, organisational innovations are always superimposed on the natural change that occurs in all organisations over time. Although the notion of obsolescence is typically associated with technology, the inherent change that is characteristic of organisations means that dynamism is a necessary characteristic of organisational innovations if they are not to become obsolete. It is thus important to analyse the implementation of any organisational innovation over time-taking into account its initial implementation, the degree of implementation over time, and future plans for the development of the implementation as circumstances change and the organisation itself evolves.

The characteristic of gradualism in implementation is closely related to the issue of dynamism noted above. Because organisational concepts take different forms over time, there is a need to differentiate between the breadth of an organisational innovation (that is, the incidence of its implementation) and the depth of that innovation (that is, whether there is a low, medium, or high level of implementation in any particular instance). Awareness of this differentiation in the gradual implementation of an organisational innovation has implications for the impact of the 
innovation on performance — as has been demonstrated by Delarue et al. (2008) in their holistic study of the effects on performance of the important organisational innovation of teamwork. Moreover, the notion of gradualism in implementation has implications for non-financial performance outcomes - such as the various attitudinal, behavioural, and operational outcomes that gradually evolve as a result of the implementation of organisational innovations.

\subsection{Environmental management systems (EMSs)}

An EMS provides a framework through which a business can control, monitor and improve its environmental impact. In Europe, two well-known standards are in common use for assessing environmental management: (i) the ISO 14000 standards of the International Organisation for Standardisation (ISO); and (ii) the Eco-Management and Audit Scheme (EMAS) of the European Commission (EC). Both of these standards seek to limit the burden that business imposes on the environment; in doing so, they produce spill-over effects in terms of environmentally friendly innovations (Ziegler and Nogareda, 2009). Both can be used as a basis for developing an effective EMS.

\subsubsection{ISO 14000 standards}

There is general agreement in the literature that the ISO 14000 standards have become the dominant international framework for environmental management (Marcus and Willig, 1997; Morrow and Rondinelli, 2002; Hillary, 2004; Marimon et al., 2006; González-Benito and González-Benito, 2008; Marimon et al. 2009). These standards were originally published in September 1996 and the most recent review occurred in 2007 (ISO, 2008). As of 31 December $2007,154,572$ certificates had been issued in 148 countries, which represented an increase of $21 \%$ on the total at the end of 2006 . The service sector accounted for $29 \%$ of certified organisations. China and Japan had the greatest number of ISO 14000-certified firms, followed by Spain in third position ( 13,852 certifications).

The ISO 14000 standard is defined as a global management system that includes the organisational structure, planning activities, responsibilities, practices, procedures, processes, and resources for preparing and applying a company's environmental policy (and also for reviewing and maintaining that policy in the future). The standard does not purport to measure the environmental impact of the companies that have implemented it; rather, it establishes methods for systematising and formalising environmentally friendly procedures. As a consequence, ISO 14000 does not deal with objectives or results, but rather with procedures (Marimon et al. 2009). 


\subsubsection{Eco-Management and Audit Scheme (EMAS)}

The other well-known standard that provides guidance in the development of an EMS in Europe is the Eco-Management and Audit Scheme (EMAS) promoted by the European Commission (EC). Although EMAS was originally intended in 1995 to be for application only in the industrial sector, the standard has, since 2001, been open to all forms of business (including public and private services). In July 2008 the EC proposed a revision of EMAS. At that time, EMAS had 4,331 registered organisations, with Germany (1,417 registrations) and Spain (1,063 registrations) being the highest-ranked nations (EMAS, 2009).

A difference between EMAS and the ISO 14000 standards is that EMAS requires compliance with certain EC environmental regulations, whereas the ISO 14000 standards merely establish a reference for the establishment of procedures in pursuit of general environmental objectives. Because of its status as a global standard, ISO 14000 holds that individual companies in various geographical locations must commit themselves to compliance with the environmental regulations in force in a particular jurisdiction.

EMAS-registered organisations are also required to make periodic environmental statements to the public in which they provide information on their environmental performance. Moreover, EMAS regulations stress the importance of employee involvement and an open dialogue with stakeholders regarding appropriate environmental management. EMAS also pays attention to the indirect environmental aspects that can result from the interaction of organisations with third parties (Albelda et al., 2007).

\subsection{Formulation of hypotheses}

The following substantive hypothesis is proposed regarding the relationship between the adoption of the ISO14000 standards and the implementation of organisational innovations in manufacturing firms:

* Hypothesis H1: There is a correlation between the adoption of the ISO14000 standards in an organisation and the use of organisational innovations.

In terms of the classification of organisational innovations suggested by Armbruster et al. (2008), two subordinate hypotheses are proposed:

* Hypothesis H1a: There is a correlation between the adoption of ISO14000 standards and the use of 'structural innovations'.

* Hypothesis H1b: There is a correlation between the adoption of ISO14000 standards and the use of 'procedural innovations'. 


\section{Methodology}

\subsection{Data}

The empirical data used to test the hypotheses were collected from the Spanish sub-sample of the 2006 'European Manufacturing Survey', which is a biannual international questionnaire that was first created by the Fraunhofer Institute for Systems and Innovation Research (ISI) in 1993 (Lay and Maloca, 2004). Among other things, the European manufacturing survey conducts a detailed study of the utilisation of organisational and technological innovations by manufacturing companies at both the intra-organisational and inter-organisational levels.

In 2006, the survey received approximately 3,500 responses from 12 European countries (Austria, Croatia, France, Germany, Greece, Netherlands, Slovenia, Spain, Switzerland, Turkey, United Kingdom, and Italy). The Spanish sub-sample of the survey consisted of manufacturing establishments (NACE codes 15-37) that have at least 20 employees. A total of 45,000 Spanish companies taken from the Spanish Statistic Institute (INE) were found to meet these requirements. Approximately $10 \%$ of such Spanish firms (4450 surveys) received the survey questionnaire, which was sent out in Spanish to the senior managers of these firms by postal mail in two rounds (April 2006 and June 2006). The final dataset for the present study consisted of 151 responses, which represented a response rate of approximately 3.5\%. Therefore, the responses had a confidence level of $83 \%$, taking into account a margin of error of $5 \%(\mathrm{p}=\mathrm{q}=0.5)$.

Table 1 presents some descriptive statistics of the sample. It is noteworthy that the mediumhigh- and high-technology industries had the highest levels of actual implementation of the ISO14000 standards, whereas the low-technology industries tended to be in the process of implementation.

Take in Table 1 about here

Table 1: Descriptive statistics of the sample according to level of technology

\subsection{Measurement}

\subsubsection{ISO 14001 standard}

A specific question was included in the European Manufacturing Survey questionnaire about the implementation of the ISO14000 standards. Firms were thus asked directly whether they had implemented this environmental standard. If the answer was in the negative, firms were asked to respond to a subsequent question in terms of two options: (i) implementation is planned in the course of the next two years; or (ii) no implementation is planned. 
This detailed and specific question thus enabled the present study to classify the firms into three groups with regard to ISO 4000 certification:

* certified companies;

* companies in the process of certification; and

* non-certified companies.

\subsubsection{Organisational innovation}

The European Manufacturing Survey also asks questions about a set of organisational innovations, among which are several of interest in the present study. The following eight organisational innovations were chosen for analysis on the basis of data from the survey:

* Four organisational innovations of relevance to subordinate hypothesis H1a (regarding the use of structural innovations): (i) 'teamwork in production'; (ii) 'integration of tasks'; (iii) 'decentralisation of planning, operating, and controlling functions'; and (iv) 'time bank for flexible labour capacity'.

* Four organisational innovations of relevance to subordinate hypothesis H1b (regarding the use of procedural innovations): (i) 'simultaneous/concurrent engineering'; (ii) ‘continuous improvement process' (CIP); (iii) 'internal zero-bufferprinciples' ('Kanban'); and (iv) 'just-in-time delivery to the costumer' ('JIT').

An exploratory factor analysis of these eight items was conducted to verify the underlying dimensions (structural and procedural) of organisational innovations. The matrix of correlations was submitted to two tests: Bartlett's spherificity test and the Kaiser-Meyer-Olkin (KMO) index. The Bartlett statistic, with a value $\chi^{2}=144.52$ (significance level of 0.000 ), confirmed the existence of linear dependence between the variables, and thus justified continuing with the procedure. The KMO (0.767) also confirmed that factor analysis was likely to generate satisfactory results (Visauta, 1998). The analysis extracted two factors. The Kaiser criterion was used to retain only those factors that presented eigenvalues of one or greater. These first two factors retained $47.0 \%$ of the initial variance, which represented a good proportion in view of the fact that each of the new components provided independent (and therefore unrepeated) information.

Take in Table 2 about here

Table 2: Principal component analysis of organisational innovations

Using varimax rotation, weightings were obtained for each factor in each of the variables (see Table 2). It is apparent that all items (individual organisational innovations) correlated strongly with one or other dimension ('structural' or 'procedural'). 
Apart from one exception, these results coincided with the classification suggested by Armbruster et al. (2008). The exception was 'simultaneous engineering', which had been situated among 'procedural innovations' by Armbruster et al. (2008) but appeared among 'structural innovations' in the present results. However, it should be noted that the loading for this item on the dimension of 'structural innovations' was only moderate and that the correlations with the other items loading on this dimension were poor (correlation between this item and the total corrected subscale was 0.303). In accordance with the criteria suggested by Sanzo et al. (2003), it was decided to discard this item from further analysis.

Having eliminated the aberrant item, the reliability of the resulting two constructs was assessed using Cronbach's alpha. The construct of 'structural innovations' had a Cronbach's alpha of 0.617 , which exceeded Malhotra's (2004) minimum criterion of 0.6 for demonstrating internal consistency. The construct of 'procedural innovations' had a Cronbach's alpha of 0.531. Although this suggested some doubt about the reliability of the second construct, the analysis proceeded (albeit with caution regarding any final conclusions thus obtained).

\section{Results}

In order to have a better understanding of the relationship between environmental management systems and organizational innovations we present Table 3.

Take in Table 3 about here

Table 3: Spreading of organizational innovations according to ISO14000

In general terms our result show highest implementation of teamwork in production (90\%), followed by CIP (75\%), integration of tasks (73\%), time-bank for flexible working hours (54\%), decentralisation of planning, operating and controlling functions (49\%), Just-In-Time delivery to the customer (43\%), Simultaneous Engineering (35\%), internal zero-buffer-principle (kanban) (28\%) among the companies that have the environmental ISO standard.

To test the first subordinate hypothesis, which referred to the relationship between the adoption of ISO14000 standards and the use of 'structural innovations', a multinomial logit model was utilised. This technique is especially appropriate for qualitative dependent variables (categorical variables). The firm's status with regard to ISO 4000 certification ('certified'; 'in process of certification'; or 'non-certified') was taken as the dependent variable, whereas 'structural' and 'procedural' innovations were taken as explanatory variables.

In addition, on the basis of the results shown in Table 1, two control variables were assumed to influence the likelihood of a company adopting ISO 14000 certification: 
* technology intensity: analysed through two binary variables to distinguish between the medium-low technology industries (designated 'medium intensity') and the mediumhigh and high technology industries (designated 'high intensity'); and

* company size (measured by the number of employees).

Three different regression models were estimated utilising these variables:

* Model 1: incorporated only the control variables (technology intensity and company size) as independent variables;

* Model 2: included only the dimensions of organisational innovations (structural and procedural); and

* Model 3: considered all the variables.

The results of these analyses are presented in Table 4.

\section{Take in Table 4 about here}

Table 4: Relationship between the dimensions of organisational innovations and the adoption of ISO 14001: multinomial logit model

It is apparent from Table 4 that Model 1, which included only the control variables (technology intensity and size) as predictors, did not appear to show a difference between the medium-intensity companies that had implemented an EMS and the medium-intensity companies that had not implemented such a system; however, there was a significant difference between the high-intensity companies that had implemented an EMS and those that had not. High-intensity technology thus appears to be a predictor of ISO 4000 certification. Moreover, this model showed that the largest firms were the first to adopt the ISO14000 standards. The remainder of the firms had initiated adoption of the standard, which might explain why there was no significant difference between 'in process' and 'non-certified' companies.

Model 2, which included only the two dimensions of organisational innovations (structural and procedural), revealed that both were good predictors of the adoption of ISO 14001, thus supporting Hypothesis 1 . There was no difference detected between 'structural' and 'procedural' organisational innovations, which indicates that both types of organisational innovations are inherent during the process of implementation of the ISO14000 standards.

However, when these variables were introduced along with the control variables in Model 3 , it is apparent that the coefficient of 'procedural' innovations was no longer significant whereas the coefficient of 'structural' innovations remained significant. This result suggests that, whereas the use of 'procedural' innovations was related to economies of scale, the use of 'structural' innovations was essential to the adoption of the ISO 14000 standards. However, the availability of resources might actually have determined the achievement of the ISO 14001 certification (given that both dimensions were positive and greater than one). 
In summary, the results provide partial support for Hypothesis H1 in that they show that the greater the use of organisational innovations (both types) in a company, the greater the likelihood that the company will adopt the ISO 14000 standards. In other words, both types of innovations are good predictors of ISO 14001 certification, but only 'structural' innovations predict anything different from that which company size and technology intensity predict. It would thus seem that only 'structural' innovations remain as a significant predictor when the variables of company size and technology intensity are taken into account.

\section{Conclusions}

This paper has studied the links between the adoption of the ISO 14000 standards and the use of organisational innovations (categorised, in accordance with Armbruster et al., 2008, into 'structural' and 'procedural' innovations).

The empirical research reported in this paper indicates that companies that have adopted the ISO14000 standards have utilised 'structural' innovations. This might be: (i) a consequence of the adoption of new standard organisational processes in these companies; (ii) a consequence of the desire of the companies to become more efficient; or even (iii) a consequence of company size.

Managers of companies with operations functions should be aware of the difficulties they might find in implementing the ISO 14000 standards and achieving certification. On the other hand, the findings of this study support the idea of compatibility between use of 'structural' innovations and ISO 14000 certification.

It is acknowledged that the use of only two items to analyse each type of organisational innovation ('structural' and 'procedural') is a limitation of the study. It is obviously desirable to expand on the present findings in this regard. Having established the general tendency of these two types of innovations in relation to the adoption of the ISO 14000 standards, it would be interesting to conduct a field study that focuses more specifically on each kind of organisational innovation using a wider variety of particular innovations for analysis.

Finally, as noted above, managers should view the adoption of ISO 14000 as an opportunity for the implementation and use of organisational innovations. ISO 14000 certification can thus be effectively used by managers to re-organise the internal operations of the firm.

\section{References}


Albelda, E., Correa, C., Carrasco, F. (2007) "Environmental management systems as an embedding mechanism: a research note", Accounting, Auditing \& Accountability Journal Vol. 20 No. 3, pp. 403-422

Armbruster, H., Bikfalvi, A., Kinkel, S., Lay, G. (2008), "Organizational Innovation - The challenge of measuring non-technical innovation on large scale surveys", Technovation Vol. 28, pp. 644-657.

Benders, J., Huijgen, F., Pekruhl, U. (2001) "Measuring group work; findings and lessons from a European Survey", New Technology, Work and Employment, 16/3, 204-217.

Daft, R. (1978) A dual-core model of organizational innovation. Academy of Management Journal, Vol. 21, Issue 2, pp. 193-210.

Damanpour, F. (1996) "Organizational complexity and innovation: developing and testing multiple contingency models". Management Science, 42 (5), pp. 693-716.

Delarue, A., Van Hootegem, G., Procter, S., Burridge, M. (2008) Teamworking and organizational performance: A review of survey-based research. International Journal of Management Reviews, Vol. 10, Issue 2, pp. 127-148.

European Commission (2002), New forms of work organization: the obstacles to wider diffusion, Business Decision Limited.

EMAS (2009) http://ec.europa.eu/environment/emas/pdf/5_5articles_en.pdf(visitada 12 de junio 09)

Damanpour, F., Evan, W.M. (1984) Organizational innovation and performance: the problem of “'Organizational Lag”. Administrative Science Quarterly 29, pp. 392-409.

González-Benito, J.,González-Benito, O. (2008) “Operations management practices linked to the adoption of ISO 14001: An empirical analysis of Spanish manufacturers" International Journal of Production Economics 113, pp. 60-73.

Hillary, R. (2004) "Environmental management systems and the smaller enterprise", Journal of Cleaner Production, Vol. 12, pp. 561-9.

ISO, (2008) http://www.iso.org/iso/iso_catalogue/ management_standards /certification/ the_iso_survey.htm (visitada 12 de junio 09)

Lam, A. (2005) Organizational Innovation, in Fagerberg, J., Mowery, D., Nelson, R. (Eds.) The Oxford Handbook of Innovation. Oxford University Press.

Lay, G., Maloca, S. (2004) "Dokumentation der Umfrage Innovationen in der Produktion 2003", Arbeitspaper des Fraunhofer ISI. Karlsruhe, June.

Lay, G., Mies, C. (1999) Flexibility at work, in Lay, G, Shapira, P., Wengel, J. (Eds.) Innovation in Production - The Adoption and Impacts of New Manufacturing Concepts in German Industry, Physica-Verlag.

Malhotra, N.K. (2004), Marketing Research and Applied Orientation (4th ed), Prentice Hall Inc, New Jersey, USA.

Marcus, P.A., Willig, J.T. (1997) Moving Ahead with ISO 14001: Improving Environmental Management and Advancing Sustainable Development, John Wiley, New York, NY.

Marimon, F., Casadesus, M., Heras, I. (2006) ISO 9000 and ISO 14000 standards: An international diffusion model. International Journal of Operations and Production Management 26 (2), 141-165.

Marimon, F.; Casadesús, M.; Heras, I. (2009) "ISO 9000 and ISO 14000 standards: a projection model for the decline phase”, Total Quality Management \& Business Excellence, 2009, Vol 20, $\mathrm{n}^{\mathrm{o}} 1$, pp. 1-21.

Ministerio de Industria, Turismo y Comercio (2005) La innovación empresarial en España. Madrid.

Morrow, D., Rondinelli, D. (2002) "Adopting corporate environmental management systems: motivations and results of ISO 14001 and EMAS certification", European Management Journal, Vol. 20 No. 2, pp. 159-71.

OECD, 2005. Oslo Manual - Guidelines for Collecting and Interpreting Innovation Data, Paris. 
Osterman, P. (1994) "How common is workplace transformation and who adopts it?", Industrial and Labour Relations Review, 47:2, 173-188.

Tidd, J., Bessant, J., Pavitt, K. (2005) Managing innovation. Integrating technological, market and organizational change. John Wiley \& Sons, Ltd.

Sanzo, M.J., Santos, M.L., Vázquez, R., Álvarez, L.I. (2003), “The effect of market orientation on buyer-beller relathioship satisfaction”, Industrial Marketing Management, Vol. 32, No. 4, pp. 327-345.

Smith, K. (2005) Measuring Innovation, in Fagerberg, J., Mowery, D., Nelson, R. (Eds.) The Oxford Handbook of Innovation. Oxford University Press.

Ziegler A., Nogareda, J.S. (2009) "Environmental management systems and technological environmental innovations: Exploring causal relationship", Research Policy, Vol. 38, pp 885893.

Visauta, B. 1998. Análisis estadístico con SPSS para Windows. Estadística Multivariante. 304 p. Editorial McGraw Hill, Madrid, España.

World Business Council for Sustainable Development (2008) What a way to run the World WBCSD Annual Review 2008.

World Economic Forum (2008) The Global Competitiveness Report 2008-2009. 
Table 1: Descriptive statistics of the sample according to level of technology

\begin{tabular}{|c|c|c|c|c|}
\hline Sample size & $\begin{array}{l}\text { Low-technology } \\
\text { industries } \\
49\end{array}$ & $\begin{array}{l}\text { Medium-low- } \\
\text { technology } \\
\text { industries } \\
49\end{array}$ & \begin{tabular}{l} 
Medium-high \\
and high- \\
technology \\
industries \\
\multicolumn{1}{c}{53}
\end{tabular} & Total \\
\hline \multicolumn{5}{|c|}{$\begin{array}{ll}\text { Number } \\
\text { employees }\end{array}$} \\
\hline $20-99$ & $29(61.7 \%)$ & $31(63.3 \%)$ & $24(50.9 \%)$ & $84(58.3 \%)$ \\
\hline $100-249$ & $13(27.7 \%)$ & $14(28.6 \%)$ & $17(35.4 \%)$ & $44(30.6 \%)$ \\
\hline$>250$ & $5(10.6 \%)$ & $4(8.2 \%)$ & $7(14.6 \%)$ & $16(11.1 \%)$ \\
\hline \multicolumn{5}{|l|}{ ISO 14001} \\
\hline Certified & $12(24.5 \%)$ & $20(40.8 \%)$ & $21(39.6 \%)$ & $53(35.1 \%)$ \\
\hline In process & $22(44.9 \%)$ & $16(32.7 \%)$ & $11(20.8 \%)$ & $49(32.5 \%)$ \\
\hline Non-certified & $15(30.6 \%)$ & $13(26.5 \%)$ & $21(39.6 \%)$ & $49(32.5)$ \\
\hline
\end{tabular}


Table 2: Principal component analysis of organisational innovations

\begin{tabular}{|l|c|c|}
\hline \multicolumn{1}{|c|}{ Items } & \multicolumn{2}{c|}{ Component } \\
\hline & $\begin{array}{c}\text { Structural } \\
\text { innovation }\end{array}$ & $\begin{array}{c}\text { Procedural } \\
\text { innovation }\end{array}$ \\
\hline $\begin{array}{l}\text { Integration of tasks (planning, operating or } \\
\text { controlling functions with the machine operator) }\end{array}$ & .720 & .177 \\
\hline Time bank for flexible working hours & .681 & .192 \\
\hline Team work in production & .632 & .118 \\
\hline $\begin{array}{l}\text { Decentralisation of planning, operating } \\
\text { and controlling functions }\end{array}$ & .593 & .830 \\
\hline Simultaneous Engineering & .504 & .701 \\
\hline Just-In-Time delivery to the customer & .257 & .583 \\
\hline Internal zero-buffer-principle (kanban) & .289 & \\
\hline CIP - Continuous Improvement Process & & \\
\hline $\begin{array}{l}\text { Extraction method: Main components analysis } \\
\text { Rotation method: Varimax normalization with Kaiser } \\
\text { Rotation converged in 3 iterations }\end{array}$ \\
\hline
\end{tabular}


Table 3: Spreading of organizational innovations according to ISO14000

\begin{tabular}{|c|c|c|c|c|c|c|c|}
\hline \multicolumn{4}{|c|}{ STRUCTURAL INNOVATIONS } & \multicolumn{4}{|c|}{ PROCEDURAL INNOVATIONS } \\
\hline & ISO & ISO & NO & & ISO & ISO & NO \\
\hline & IMP & PROCESS & ISO & & IMP & PROCESS & ISO \\
\hline \multicolumn{4}{|c|}{ Teamwork in production } & \multicolumn{4}{|c|}{ CIP - Continuous Improvement Process } \\
\hline YES & $90.57 \%$ & $79.59 \%$ & $67.35 \%$ & YES & $75.47 \%$ & $67.35 \%$ & $46.94 \%$ \\
\hline \multirow[t]{2}{*}{ High } & $47.62 \%$ & $37.50 \%$ & $44.44 \%$ & High & $51.35 \%$ & $28.13 \%$ & $28.57 \%$ \\
\hline & & & & Mediu & & & \\
\hline \multirow{2}{*}{$\begin{array}{r}\text { Medium } \\
\text { Low }\end{array}$} & $40.48 \%$ & $56.25 \%$ & $44.44 \%$ & $\mathrm{~m}$ & $32.43 \%$ & $53.13 \%$ & $61.90 \%$ \\
\hline & $11.90 \%$ & $6.25 \%$ & $11.11 \%$ & Low & $16.22 \%$ & $18.75 \%$ & $9.52 \%$ \\
\hline NO & $9.43 \%$ & $20.41 \%$ & $32.65 \%$ & NO & $24.53 \%$ & $32.65 \%$ & $53.06 \%$ \\
\hline \multicolumn{4}{|c|}{$\begin{array}{l}\text { Integration of tasks (planning. operating or } \\
\text { controlling functions with the machine operator) }\end{array}$} & \multicolumn{4}{|c|}{ Just-In-Time delivery to the customer } \\
\hline \multirow[t]{3}{*}{ YES } & $73.58 \%$ & $61.22 \%$ & $65.31 \%$ & YES & $43.40 \%$ & $38.78 \%$ & $32.65 \%$ \\
\hline & $40.54 \%$ & $32.14 \%$ & $33.33 \%$ & High & $42.86 \%$ & $41.18 \%$ & $30.77 \%$ \\
\hline & $45.95 \%$ & & $56.67 \%$ & $\begin{array}{r}\text { Mediu } \\
\mathrm{m}\end{array}$ & $28.57 \%$ & $35.29 \%$ & $61.54 \%$ \\
\hline $\begin{array}{r}\text { Medium } \\
\text { Low } \\
\end{array}$ & $13.51 \%$ & $14.29 \%$ & $10.00 \%$ & Low & $28.57 \%$ & $23.53 \%$ & $7.69 \%$ \\
\hline NO & $26.42 \%$ & $38.78 \%$ & $34.69 \%$ & $\mathrm{NO}$ & $56.60 \%$ & $61.22 \%$ & $67.35 \%$ \\
\hline \multicolumn{4}{|c|}{ Time bank for flexible working hours } & \multicolumn{4}{|c|}{ Simultaneous Engineering } \\
\hline \multirow{2}{*}{$\begin{array}{l}\text { YES } \\
\text { High }\end{array}$} & $54.72 \%$ & $48.98 \%$ & $40.82 \%$ & \multirow{2}{*}{$\begin{array}{c}\text { YES } \\
\text { High } \\
\text { Mediu }\end{array}$} & $35.85 \%$ & $16.33 \%$ & $12.24 \%$ \\
\hline & $33.33 \%$ & $18.18 \%$ & $21.05 \%$ & & $38.89 \%$ & $42.86 \%$ & $33.33 \%$ \\
\hline \multirow{2}{*}{$\begin{array}{r}\text { Medium } \\
\text { Low }\end{array}$} & $37.04 \%$ & $54.55 \%$ & $57.89 \%$ & \multirow{2}{*}{$\begin{array}{r}\mathrm{m} \\
\text { Low }\end{array}$} & $44.44 \%$ & $28.57 \%$ & $50.00 \%$ \\
\hline & $29.63 \%$ & $27.27 \%$ & $21.05 \%$ & & $16.67 \%$ & $28.57 \%$ & $16.67 \%$ \\
\hline NO & $45.28 \%$ & $51.02 \%$ & $59.18 \%$ & NO & $64.15 \%$ & $83.67 \%$ & $87.76 \%$ \\
\hline \multicolumn{4}{|c|}{$\begin{array}{l}\text { Decentralisation of planning. operating } \\
\text { and controlling functions }\end{array}$} & \multicolumn{4}{|c|}{ Internal zero-buffer-principle (kanban) } \\
\hline \multirow{2}{*}{$\begin{array}{l}\text { YES } \\
\text { High }\end{array}$} & $49.06 \%$ & $28.57 \%$ & $24.49 \%$ & \multirow{2}{*}{$\begin{array}{c}\text { YES } \\
\text { High } \\
\text { Mediu }\end{array}$} & $28.30 \%$ & $12.24 \%$ & $10.20 \%$ \\
\hline & $16.67 \%$ & $35.71 \%$ & $20.00 \%$ & & $33.33 \%$ & $100.00 \%$ & $40.00 \%$ \\
\hline Medium & $70.83 \%$ & $50.00 \%$ & $60.00 \%$ & $\begin{array}{r}\text { medu } \\
\text { m }\end{array}$ & $37.04 \%$ & $0.00 \%$ & $60.00 \%$ \\
\hline Low & $12.50 \%$ & $14.29 \%$ & $20.00 \%$ & Low & $29.63 \%$ & $0.00 \%$ & $0.00 \%$ \\
\hline NO & $50.94 \%$ & $71.43 \%$ & $75.51 \%$ & NO & $71.70 \%$ & $87.76 \%$ & $89.80 \%$ \\
\hline $\mathbf{N}$ & 53 & 49 & 49 & & 53 & 49 & 49 \\
\hline
\end{tabular}


Table 4: Relationship between the dimensions of organisational innovations and the adoption of ISO 14001: multinomial logit model

\begin{tabular}{lcccccc} 
& Model 1 & \multicolumn{3}{c}{ Model 2 } & Model 3 & \\
\cline { 2 - 7 } & In process & Certified & In process & Certified & In process & Certified \\
& ISO14001 & ISO 14001 & ISO14001 & ISO 14001 & ISO14001 & ISO 14001 \\
\hline Constant & 0.995 & $0.303^{* *}$ & 1.423 & 1.433 & 1.831 & 0,490 \\
Med intensity & 0.938 & 2.362 & & & 0.665 & 1,858 \\
High intensity & $0.355^{* *}$ & 0.860 & & & 0.430 & 1,125 \\
Size & 1.004 & $1.008^{* * *}$ & & & 1.001 & $1,005^{* *}$ \\
Structural & & & 1.385 & $2.059^{* * *}$ & 1.339 & $2,005^{* * *}$ \\
Procedural & & & 1.456 & $1.588^{*}$ & 1.508 & 1,290 \\
Likelihood & & $22.255^{* * *}$ & & $13.184^{* * *}$ & & $26,538^{* * *}$ \\
$\mathrm{R}^{2}$ (Cox) & 0.143 & & 0.096 & & 0,191 \\
$\mathrm{R}^{2}$ (Nagelkerke) & 0.161 & & 0.108 & & 0.215 \\
$\mathrm{R}^{2}$ (McFadden) & 0.07 & & 0.046 & & 0.097 \\
\hline
\end{tabular}

